\title{
Change in store? An investigation into the impact of the book superstore environment on use, perceptions and expectations of the public library as a space, place and experience
}

\author{
Helen Cartwright
}

\section{Author}

Helen Cartwright is an Assistant Librarian at the Foreign \& Commonwealth Office. She graduated from the University of Sheffield with an MA in Librarianship in September 2001, and previously worked at the J.B. Morrell Library, University of York.

Email: helen.cartwright@fco.gov.uk

\begin{abstract}
The book superstore is promoted not just as a place to buy books but also as a community resource in which to read, learn and socialise: traits that have in combination traditionally been the preserve of the public library. This study investigates the impact of the bookstore environment on public library space. The attitudes and behaviours of library and bookstore users were examined through focus group interviews and a self-completed questionnaire. Clear areas of overlap in the functions of the two sites were found, as was evidence of age and income-related splits in use and perception of bookstores and libraries. Results suggest attention should be paid to the beliefs and behaviours of young people and middle-income earners (the groups most noticeably increasing their use of the bookstore) and to the desired balance of education and recreation in the image and nature of the public library.
\end{abstract}

\section{Occasion}

This paper reports the main findings of a Masters dissertation submitted at the University of Sheffield in September 2001 and awarded 'Very Highly Commended' in the LIRG Postgraduate Prize 2002. The full dissertation is available at: http://dagda.shef.ac.uk/dissertations/2000-01/cartwright.pdf

\section{Acknowledgements}

Thanks are due to all those individuals in libraries and bookstores who completed questionnaires or took part in focus groups, and to staff in all participating sites for their co-operation, thoughts and ideas. Thanks to Bob Usherwood for guidance and support throughout.

\section{Introduction}

Once unknown outside a few large US cities, the book superstore is now an increasingly familiar sight on the British high street. Characteristically large, with reading space, cafés, events and exhibitions, the bookstore has been described not 
simply as a place to buy books, but as a 'venue': a space for 'education, fun and interaction' (Smith, 1999:31) in which individuals are 'encouraged to linger - to drink coffee, meet their friends, read magazines, listen to music or to an author reading' (Sanderson, 2001:26). Some commentators have gone further, suggesting the bookstore exemplifies 'recreational' or 'lifestyle' shopping in which purchasing is seen to have only a 'marginal' role to play (Falk, 1997:183), and in which traditional boundaries between public and private space have become blurred (Ritzer, 1999:132). Kotler and Armstrong (2001: 494) describe the bookstore as 'part bookstore, part library, part living room'.

Both the US and UK book retailing and library literature is replete with articles and commentaries in which the public library and the book superstore are juxtaposed (e.g. Forrest, 2001; Sannwald, 1998; St Lifer, 2001; Coffman, 1998). As far back as 1995, the ASLIB review of the UK public library service referred to the emergence of the book superstore in the US as a 'significant development' likely to be a 'harbinger' of changes in Britain, and to have a 'substantial impact on libraries' (ASLIB, 1995:65). More recently it has been suggested that 'the new players in the business believe that soon they will be filling the role of the sadly neglected public library system in Britain' (Buckingham and Finch, 1998:26), and that 'the last bastion of social space, the library ... is frequently becoming a victim of spending cuts and is often underresourced and under-used. In this situation, the bookshop can fill a gap and provide a place ... people can treat as their own community space' (Smith, 1999:31). More recently still, reports published in 2003 by both DCMS and The Audit Commission ${ }^{2}$ call explicitly on libraries to consider what attracts readers to bookstores.

Whilst there has been much speculation about the effect of the book superstore on the public library, there is little available research-based evidence on the subject. The aim of this project was therefore to examine the impact of the high-street book superstore environment on use, perceptions and expectations of public library space in the UK. By investigating how users of library and bookstore space feel about and utilise each site, and by charting trends in behaviour and attitudes towards the two locations, it was hoped to reach a fuller understanding of how the book superstore and public library are currently perceived, used and experienced 'on the ground'.

\section{Methodology}

With interest here focused on exploring the 'meaning' and interplay of the space and place of the public library and the book superstore, a qualitative methodological approach was adopted to gather rich insights into the attitudes and experiences of library and bookstore users. The selection of the population to be studied was guided by the principles of purposive sampling: parties and sites were chosen with regard to their capacity to shed light on the topics under investigation (Walliman, 2001). Research was carried out in central libraries and book superstores in five UK cities during the summer of 2001. Although the libraries involved varied in size and nature, all were located within walking distance of a book superstore offering facilities such as reading space, cafés, and events. Three distinct and complementary research instruments were employed across ten case study sites (one central library and one book superstore in each city) in order to produce differing forms of data and to draw as wide a range of 'voices' as possible into the study. 
Focus group interviews, facilitating reflection, discussion and debate, were held with pre-existing reading or discussion groups at three of the bookstores and three of the libraries involved in the study. Group size varied from 3 to 12, with interviews lasting between 15 and 30 minutes. Although an interview guide was used in each session, a flexible and conversational style was maintained. Participants were asked to reflect on their experiences of using or simply 'being in' public libraries and bookstores, to consider functions and roles ascribed to both sites in the literature, to discuss their perceptions of the similarities and differences between bookstores and libraries, and to reflect on whether or not library and bookstore environments should look and feel different from each other.

A self-completed user questionnaire was placed in each of the case study sites. The questionnaire was designed to elicit information on: patterns and frequency of use of bookstores and public libraries; 'in-site' behaviour; demographics of users of library and bookstore space; and further data on perceptions and expectations of libraries and bookstores. A combination of closed questions, attitude measurement scales, semantic differential scales and open questions was used. To maximise interest and engagement, 'symmetrical' versions of the questionnaire were produced to ensure library users were asked about libraries before introducing questions about bookstores, and bookstore users were asked about bookstores before libraries. 500 copies of the questionnaire were distributed (50 in each case study site) with a view to achieving a return of $10 \% .120$ completed questionnaires were returned in total (48 from libraries and 72 from bookstores); the final response rate was therefore $24 \%$, with almost all socio-economic groups being well represented in the sample ${ }^{2}$.

Semi-structured interviews were also held with bookstore and library staff at nine of the sites involved in the study. Although the views of users of public library and bookstore space were of key interest, it was also recognised that staff and professionals would be uniquely placed to offer different and highly relevant perspectives on the issues under investigation. A topic guide was used to ensure interviewees were consulted on the same general themes whilst maintaining a necessary flexibility.

Given the inductive nature of the research, an appropriately qualitative approach to data analysis was adopted in which 'salient themes, recurring ideas or language' (Marshall \& Rossman, 1999:154), the 'clues' to new concepts and theory (Walliman, 2001), were sought. Data from focus groups, semi-structured interviews and open questions included in the questionnaire were 'cleaned' by 'coding' responses into typologies and then interpreted by exploring emerging relationships between typologies. On-going analysis ensured emerging concepts could be further tested in the field. Basic descriptive statistical analysis of the closed questions and attitude measurement scales developed for the questionnaire was also undertaken and the results used to inform concepts arising from the qualitative data. Descriptive analyses of demographic data enabled profiles of users and use patterns in each site to be drawn, and for attitudinal material to be cross-referenced with socio-economic indicators.

\section{Results}


In keeping with the goals of qualitative research, the aim of this project was to illuminate a social phenomenon rather than provide statistically valid 'answers' or globally applicable findings. In the results outlined below, participants speak for and of themselves; recording their 'stories' thus begins a process and one specific approach to understanding how the bookstore may be impacting upon the public library. An overview of images and impressions held of the public library and book superstore by those participating in the project is followed by a discussion of perceptions and use of both sites as community space, and of 'in-site' behaviour. Themes arising during the course of the project - stock, display and user-friendliness are then considered, and are followed by an examination of user-desired 'futures' for both the library and the bookstore.

\section{Image and impression}

To explore impressions held of the bookstore and the public library, image profiles or 'site personalities' were constructed for each location from project participants' ratings of environmental and functional characteristics ascribed to both public libraries and bookstores in the literature. Questionnaire respondents were asked to indicate which word in each of 14 pairs they felt best described the library and the bookstore (see Figure 1). Respondents were, for example, asked to comment on the comfort of each site by indicating whether they regarded the library and (at a later point in the questionnaire) the bookstore as 'very', or 'quite' comfortable, 'very' or 'quite' uncomfortable, or 'neutral' in terms of comfort. Ratings for each characteristic were converted to numerical data (1-5) and image profiles then constructed and charted by totalling and averaging the scores. Data on image and impression were also drawn from responses to open questions included in the questionnaire and presented in focus group interviews in which participants were asked to describe the 'look and feel' of the library and the bookstore, and the main differences in the 'look and feel' of each site.

\begin{tabular}{|c|c|c|c|c|c|c|}
\hline \multicolumn{7}{|c|}{$\begin{array}{l}\text { Which of these words or phrases do you think best describes public libraries? Place an ' } \mathrm{X} \text { ' } \\
\text { in one box on each line. [Question repeated for bookstores at a later point in the } \\
\text { questionnaire] }\end{array}$} \\
\hline & $\begin{array}{l}\text { Very } \\
\leftarrow \\
\end{array}$ & $\begin{array}{l}\text { Quite } \\
\leftarrow\end{array}$ & Neutral & $\begin{array}{r}\text { Quite } \\
\rightarrow\end{array}$ & $\begin{array}{r}\text { Very } \\
\rightarrow \\
\end{array}$ & \\
\hline Warm, light \& airy & & & & & & Dark, cold \& stuffy \\
\hline Modern \& up-to-date & & & & & & Unfashionable \& behind the times \\
\hline Comfortable & & & & & & Uncomfortable \\
\hline Smart \& clean & & & & & & Tatty \& dirty \\
\hline Intimidating & & & & & & Welcoming \& friendly \\
\hline A safe place to be & & & & & & A place in which I do not feel safe \\
\hline Noisy \& bustling & & & & & & Quiet \& calm \\
\hline Unhelpful & & & & & & Helpful \\
\hline Recreational & & & & & & Educational \\
\hline Inconvenient & & & & & & Convenient \\
\hline Relaxed & & & & & & Formal \\
\hline Functional & & & & & & Stylish \\
\hline Dull \& Boring & & & & & & Stimulating \& Inspiring \\
\hline Commercial & & & & & & Non-commercial \\
\hline
\end{tabular}

Figure 1: Semantic Differential Scale on Library and Bookstore Image (used in Questionnaire) 


\section{Refereed article}

Respondents were asked to outline their perceptions of each location regardless of the extent to which they actually used public libraries and book superstores. While results therefore include the views of library respondents who never use bookstores, and bookstore respondents who never use public libraries, the majority of those participating in the project ( $82 \%$ ) were in fact found to make at least some use of both locations. The following 'personalities' can therefore be regarded as largely informed by some degree of personal experience of each site.

Examination of the site personalities constructed from questionnaire respondents' ratings of given characteristics revealed that bookstore respondents regarded both bookstores and libraries as helpful and quiet places, but also viewed the bookstore as warmer, smarter, more comfortable, more welcoming, and more stimulating than the library. Respondents from libraries rated public libraries in more positive terms, regarding them as more welcoming, more helpful and safer places than bookstores. It was found, however, that library respondents generally viewed the bookstore environment more positively than bookstore respondents viewed the library environment, and that library respondents regarded bookstores as warmer, smarter, more comfortable and more modern than public libraries. These patterns are reflected in focus group interviewees' and questionnaire respondents' own descriptions of the 'look and feel' of the library and of the bookstore. Illustrative examples are presented in Figures 2 and 3.

\section{Bookstores:}

'Friendly \& modern'; 'Up to date, helpful environment'; 'Very relaxing \& accessible'; 'It's one of these airy, inviting places'

\section{Libraries:}

'A bit forbidding, inaccessible'; 'Serious, uptight, studious'; 'Dull, dirty, dated, dusty'; 'Useful, functional, organised'; 'pleasant but formal'; 'well-meaning but shabby'

\section{Main differences in look and feel?}

'Libraries never seem to generate any feeling of excitement - [the bookstore] does!'; '[The bookstore] is more light \& airy \& comfortable'; 'Public libraries are publicly owned and are poor'; 'Space: [the bookstore] feels open, light, uncluttered; public libraries feel cramped, messy'; '[The bookstore] pleasanter on the whole, but in libraries the books are FREE'

Figure 2: The 'Look and Feel' of Libraries and Bookstores: Bookstore Respondents

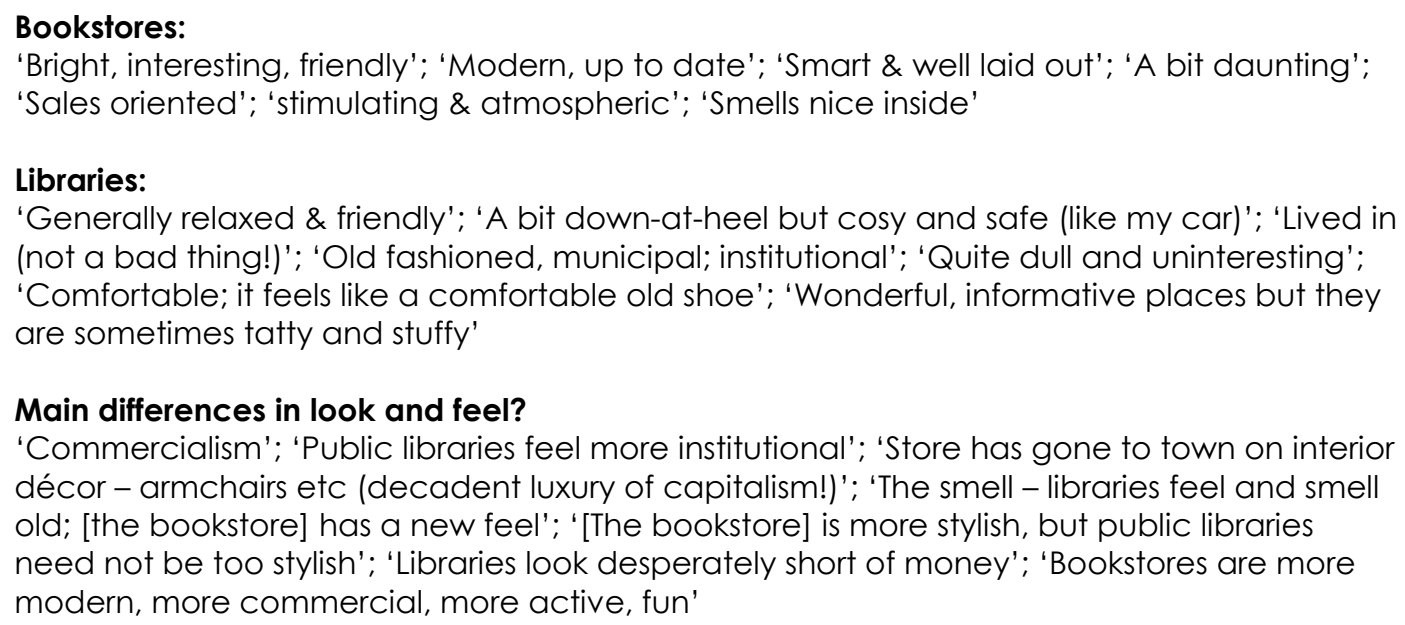


Figure 3: The 'Look and Feel' of Libraries and Bookstores: Library Respondents

As basic demographic information was provided by almost all questionnaire respondents, impressions of each site were further analysed to identify any trends linked to gender, age, occupation, income and educational qualification.

Female respondents were found to view the library environment more positively than did male respondents, in particular rating it as more comfortable and more welcoming. Analysis of response by age revealed younger respondents (17-29) viewed libraries in a noticeably more negative light than older respondents $(60+)$; older respondents were found to view the library as much smarter, more stylish and more recreational than did younger respondents. Younger respondents in both groups were also found to hold a more positive image of the bookstore than did older respondents, viewing it as more modern, safe, helpful, and convenient (younger library respondents) and warmer, safer, more relaxed, more modern, and more stimulating (younger bookstore respondents). In addition, younger respondents were found to regard the bookstore as more recreational than did older respondents. Analysis by income revealed that respondents with a household income of up to $£ 12,000$ viewed the library environment more positively than higher earners in both the library and bookstore 'sub-populations'. Respondents in the lower income brackets were found to rate the library as warmer, smarter, safer, more modern, more comfortable, and more welcoming, helpful, convenient and stimulating than did higher earners. Income was not found to influence perception of the book superstore environment. Trends relating to education and occupation were not found in this study.

\section{A place for the community?}

To investigate further the current 'meaning' of the bookstore and the public library for their users, participants were asked to reflect on both sites in relation to the concept of community space. While the library has long been characterised as a place for the community (a 'public space for all strata of society' (McGuigan, 1996:72), 'at the heart of community life almost everywhere' (Greenhalgh, 1995:167)), the bookstore has also recently been described as a provider of community space. In the US, the bookstore has been termed a 'surrogate community center' (Przybys, 2000) and in the UK a 'neutral venue that people treat as their own community space' (Smith, 1999:31). Book chains in the UK too attest to a keen interest in 'being part of', and 'at the heart of' local communities (Torsi, 2001; MacLehose \& Kneale, 2000). To explore this apparent 'blurring' of roles between the bookstore and the library, questionnaire respondents were asked to what extent they agreed that the bookstore and the library are 'places for the community'.

High levels of support for the concept of the public library as community space were found, with $94 \%$ of library respondents and $74 \%$ of bookstore respondents agreeing or strongly agreeing with the statement 'the library is a place for the community'. Although views on the bookstore as community space were found to be much more mixed, with only $36 \%$ of library respondents expressing some level of agreement with the statement that the bookstore is a 'place for the community', almost half of all bookstore respondents $(49 \%)$ were found to agree or strongly agree with the statement. Analysis of the sample as a whole further revealed that twice as many 
male respondents as female respondents strongly agreed that the book superstore represents a community space.

In addition to gathering user opinion on this subject, information supplied by questionnaire respondents was used to shed light on the extent to which each site currently serves as a place for the community. Demographic data and data regarding use patterns of each location were examined to gain at least an impression of who uses each site, and thus whether or not each site does indeed function as a space 'for all' (results here of course reflecting the views of questionnaire respondents rather than all users of libraries and bookstores).

Higher proportions of male respondents and respondents aged between 17-29 were found in the bookstore sample than in the library sample. Of the different age groups, respondents in the 17-29 bracket were also found to have increased their use of the bookstore more than any other age group during the last year, and to have increased their use of the library but to a lesser degree. Setting patterns of use against income revealed higher proportions of low-income earners in the library sample than in the bookstore sample. Those with a lower household income were also found to be increasing their use of the library and only slightly increasing their use of the bookstore. Middle-income earners were however found to be decreasing their use of the library and increasing their use of the bookstore. Although income has not been found to influence perception of each site as community space or space 'for all', it does therefore appear to influence the extent to which each location is actually used. Results from this study suggest that the library and bookstore may in effect be serving as 'community space' for two 'communities' largely separable by income.

\section{A place to linger?}

Behaviour in the bookstore and the library, and behaviours associated with the bookstore and the library, were studied to investigate further the roles and perceived roles of each site. Strong echoes exist between descriptions of library and bookstore space and function in the literature: the library is characterised as 'a safe and comfortable haven' (Landry, 1993:7), a place with 'a hard to leave atmosphere' (Greenhalgh, 1993:9), 'a street-corner university' (LIC, 2000a), a 'secure risk-free social place' (LIC, 2000b), a place for 'people to meet or just be together' and a place one can use in 'an incidental and unharassed way' (Landry, 1993:11); the bookstore is described as a 'comfortable, pressure-free environment in which to explore, listen and discover' (Torsi, 2001), a place for 'education, fun and interaction' (Smith, 1999:31), a place that can 'provide information..., entertain... help pass the time [and] provide a place to meet friends' (Pennington, 1997:39), an 'oasis, a haven' (Lee, cited by Gregory, 1998), and 'a social club' (Krietzman, 1999:36). Participants in this study were therefore asked to what extent they used the library and bookstore as places to linger, to sit, read or rest, to study or work, to find information, to socialise and to 'escape'. General comments of focus group respondents on 'in-site' behaviours and experiences were also considered.

Analysis of responses to the statements that the library and the bookstore represent 'a place in which I like to linger' revealed that while questionnaire respondents preferred to linger in their 'own' site (be it the bookstore or the library), bookstore respondents were less likely to regard the library as a place in which they like to linger than library respondents were to regard the bookstore in this way. Younger bookstore respondents 


\section{Refereed article}

were found to be particularly unlikely to regard the library as a place in which they like to linger: $85 \%$ of bookstore respondents who disagreed or strongly disagreed that the library was a place in which they liked to linger were found to be under 45 , despite only $63 \%$ of the whole bookstore sample falling into this age group. Studying typical length of visit (as also indicated by questionnaire respondents) revealed that whilst longer visits were more common to the library than to the bookstore, more than $25 \%$ of bookstore respondents were found typically to spend more than one hour in the store.

Focus group comments provide further insights into the nature of library and bookstore visits. Library visits were frequently described by both library and bookstore respondents as more functional and well defined than visits to the bookstore:

'I'm going in [to the bookstore] for pleasure; I'm going in on a much more focused reason into a library';

'The times I've chosen to go to the library have been when I've actually wanted information about something rather than just coming to have a look';

'The bookstores are consciously trying to keep you here whereas with a library you feel as if you want to leave after you've chosen your books'.

Both sites were found to be spaces in which their users like to sit, read or rest. Questionnaire results from this study suggest that bookstore respondents sit, read or rest in the bookstore more than library respondents sit, read or rest in the library. Participants of bookstore focus groups were also found to regard in-store reading positively: 'it's a great place to come to read a book off the shelves or your own book'; 'it's the way they have the sofas laid out. You're actually encouraged to flick through and read'. A perception that libraries lack comfortable seating and facilities conducive to sitting, reading or resting was identified in a number of focus group discussions:

'There are only those hard-backed chairs... there's nowhere to plonk yourself down and spread yourself out... just those tables but they're sort of for the type of man who reads the newspaper';

'I think the café makes a difference [in the bookstore]. A big difference. You can come here and just relax. In [name of town] we've got a newish libraryit's got a seating area with a vending machine but even that isn't, you know, it isn't the same';

'The fact that [the bookstore's] got loos and things like that - I mean, public libraries don't. Well, not all of them. These things are important to those of us who are older'.

Unsurprisingly perhaps, the library was found to be used much more frequently than the bookstore as a place to study or work. $67 \%$ of library respondents and $49 \%$ of bookstore respondents stated they sometimes or often used the library as a place in which to study or work, whereas no library respondents and only $24 \%$ of bookstore respondents stated that they often or sometimes used the bookstore in this way. 
Focus group data further suggested the library is strongly associated with this type of activity. The library was also found to be used more frequently than the bookstore as a place to find information. $92 \%$ of library respondents and $74 \%$ of bookstore respondents stated they often or sometimes used the library for this reason. Use of the bookstore to find information, whilst less common, was not, however, found to be rare: $63 \%$ of library respondents and $68 \%$ of bookstore respondents stated that they often or sometimes used the bookstore for this reason. Data from this project suggest an increase in use of the public library as a place in which to study or to find information when compared with previous studies of library use (Bohme \& Spiller, 1999; Insight, 1999).

Exploration of the extent to which the bookstore and library are used as places in which to meet friends or socialise by questionnaire respondents revealed that respondents more frequently socialise in their 'own' location (i.e. the site responded from) than the 'other' location. However, although numbers were low, it was also found that library respondents were twice as likely to meet friends or socialise in the bookstore than bookstore respondents were to meet friends or socialise in the library. Focus group findings add weight to the suggestion that the bookstore is generally perceived as a somewhat more recreational and social site than the library. Asked to share experiences of using bookstores and libraries, one participant of a library group commented 'I love libraries... but I'm aware I don't use them half as much as I used to. I used to meet people in the library; I used to meet half of [name of town] down the library and now I don't'. The comments of another library user suggest that where the library is serving as a vital meeting place, socialising may still not be regarded as a key aspect of 'libraryness'; 'Well, like this afternoon [at the reading group] - I'm not thinking of it as a library. I'm thinking of it as a group of friends - somewhere to meet'. In contrast, participants of bookstore focus groups and bookstore questionnaire respondents frequently referred to the bookstore as a social space: 'it's nice to just sit around and listen to people talk about books..."; "bookshops are having to work on establishing relationships with people... it works as a social space';

'I don't go to libraries very often. I did as a child but you still have this view of, like, silence - don't make too much noise or whatever. So it's much nicer to be somewhere where there doesn't have to be complete silence - and other people browsing and chatting, and passing comment when you pick up a book is actually quite a nice part of the whole experience';

If you were asking a 17 year old that uses a library and a bookshop, the bookshop is fun and nice and you have a look at the books and you might buy one, you go and have a hot chocolate and sit with your mates and chat your socks off. Whereas [when my daughter] goes to the library it's solid work - she gets up in the reference section and she can use the computer and that's the difference'.

Both sites were found in this study to serve as somewhere to 'escape to' for their own respondents. Library respondents described the library as 'my spiritual home', a 'home from home' and 'an escape from the noisy modern world'. Bookstore respondents similarly described the bookstore as a "place to be in if in dire need to uplift mood', a 'wonderful place to escape to' and 'a haven from the bustle of a busy life'. Analysis of questionnaire respondents comments indicated that while $69 \%$ of library respondents agreed that the library was a place in which they could escape, 
only $38 \%$ of bookstore respondents regarded libraries in this way, with $42 \%$ disagreeing with the statement. Bookstores were regarded by $76 \%$ of bookstore respondents as a place in which to escape, with only $36 \%$ of library respondents agreeing with the statement, and $29 \%$ actively disagreeing that the bookstore was a place in which they could escape.

Clear areas of overlap have therefore been found to exist in the ways that bookstores and libraries are being used. The results of this study of in-site behaviour also suggest that the library is more widely seen and used as a place for study, information and defined 'retrieval', whilst the bookstore is more widely seen and used as a place for recreation, socialising and browsing.

\section{Stock and display}

To stimulate further discussion and thought on the bookstore and the public library, questionnaire respondents and focus group participants were asked not just to describe the 'look and feel' of the library and the bookstore, but also to identify the 'major difference' in the look and feel of each site. The subjects of stock and display were raised frequently by participants in response to both questions.

Although mixed views were found to exist on the relative merits of bookstore stock, with a small number of respondents expressing dissatisfaction with the variety and choice available in the store, many more respondents were found to be positive about the nature and range of bookstore stock, and indeed cited this as a defining characteristic of the store experience. Library stock, where mentioned, was praised by some for its archival nature but was more frequently described as narrow or dated. A number of library and bookstore focus group participants did, however, note the library's capacity and willingness to obtain items on request. The comments of users are fairly reflected by the examples provided in Figure 4.

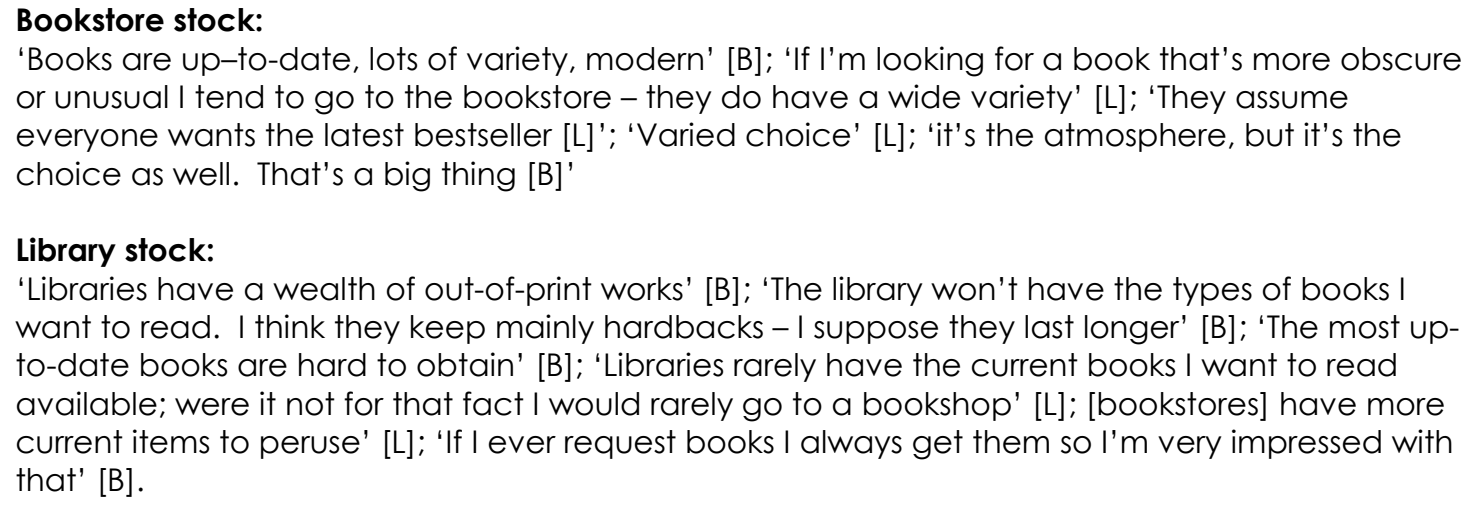

Figure 4: Views on Bookstore and Library Stock

$[\mathrm{B}=$ Bookstore respondent, $\mathrm{L}=$ Library respondent $]$

Display in bookstores was subject to some criticism by a small number of users; most respondents choosing to comment on bookstore display were, however, found to be very enthusiastic about methods used. Bookstore respondents in particular commented on ease of browsing and promotion of material in the store when considering the look and feel of the bookstore. Unlike the bookstore, the public library was not here found to be strongly associated with effective display and 


\section{Refereed article}

promotion. Only a small number of participants referred to display techniques when considering the look and feel of the library, and only one participant did so in positive terms, praising the 'table top' display of 'bestsellers' in her local library. Examples of comments by library and bookstore respondents are again provided in Figure 5.

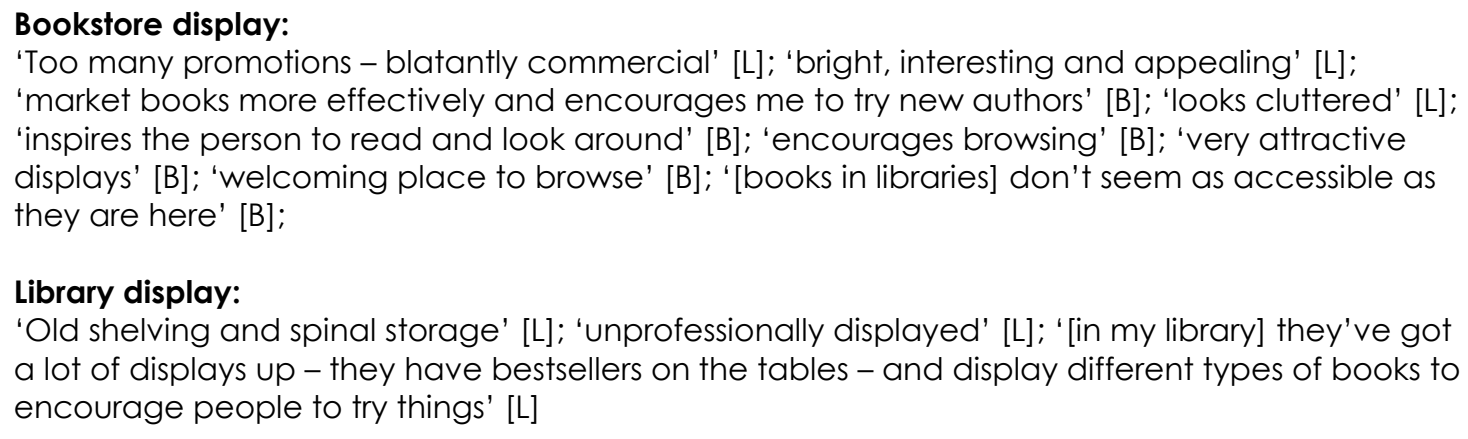

Figure 5: Views on Bookstore and Library Display

$[\mathrm{B}=$ Bookstore respondent, $\mathrm{L}=$ Library respondent $]$

\section{User-friendliness}

In addition to comments on stock and display, frequent observations about the userfriendliness of the bookstore and library were made when participants were asked to consider the 'look and feel' of the two sites. Many respondents commented on the ease (or otherwise) of finding their way and finding items in the bookshop and library, with users generally finding their 'own' site easier to use than the other site, be it the library or the bookstore. More striking remarks were, however, made about staff in both locations.

Bookstore staff were here referred to in positive terms by all bookstore respondents choosing to comment on this subject, being described as helpful, professional and enthusiastic. A number of bookstore respondents also focused on staff attributes and aspects of customer service when describing the major difference between the look and feel of the bookstore and library, rating bookstore staff and service more favourably than library staff and service. Those library respondents who chose to comment on bookstore staff, while not numerous, were critical of bookstore staff and regarded library staff as far superior in terms of reliability, helpfulness and expertise. Other library respondents described the library as welcoming and friendly. It was found that bookstore respondents, more obviously critical of library staff than library respondents, doubted not the expertise of library staff but commented instead on a perceived lack of enthusiasm and customer care skills. Examples of comments are provided in Figure 6.

\section{Bookstore Respondents:}

[Bookstore staff are] 'friendly', 'helpful', 'professional', 'enthusiastic'; 'Bookstore feels like it's there to help; libraries like you are incidental and a bit of a nuisance'; 'The bookstore has a friendlier atmosphere than public libraries I have visited'; '[Bookstore staff are] very helpful... very respectful to older people... and interested - they'll look further'; 'In public libraries more of the people (staff not included) actually look like they're interested in reading'; [Library staff are] 'well-meaning', 'uptight', 'negative outlook'; [Bookstore is] more modernised and customer focused'; I know l'll get good advice [in the bookstore]; ' [In the library] you hardly dare speak to the person behind the desk' 


\section{Refereed article}

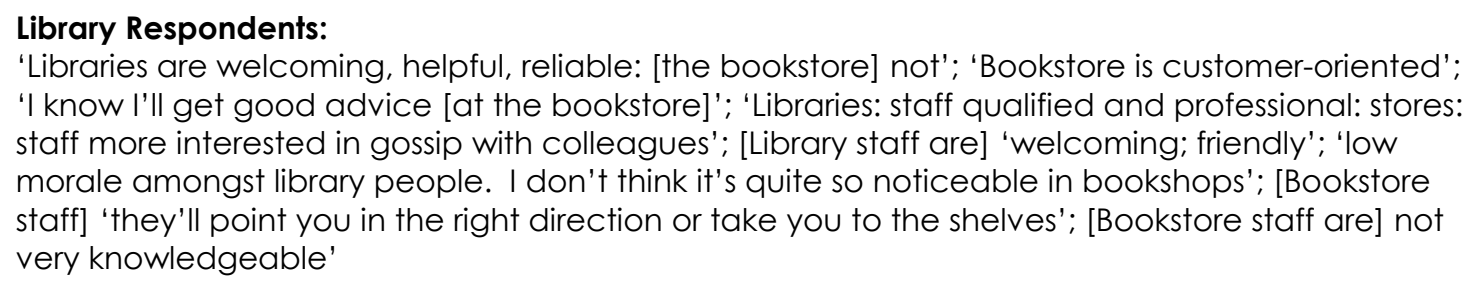

Figure 6: Views on Bookstore and Library Staff

\section{Desired futures}

As a final step towards understanding the relationship between the public library and the book superstore, participants were asked to outline how each site could be made more appealing to them, and to reflect on whether or not the library and bookstore should look and feel different from one another.

In describing a more appealing book superstore, respondents from bookstores were found to focus on environmental and service-related aspects of the store experience ('even less noise!'; 'more chairs \& tables \& sofas'; 'squishy armchairs and more of 'em'; 'more book recommendations'; 'more children's events'; 'more lunchtime events'), with only $7 \%$ of bookstore respondents referring to financial improvements such as cheaper books or better offers on titles. It is suggested that this finding further indicates that the store serves for many as a 'destination' rather than simply a site for the purchase of books. Although a higher percentage of library respondents $(21 \%)$ expressed a desire for cheaper books, library respondents too requested more in-store seating ('more seating facilities'; 'places to sit down'), in addition to access to public catalogues and online databases ('Bookfinders that customers can use themselves'; 'Computer showing 1) location of books in stock, 2) books in print').

Examination of descriptions of a more appealing library revealed that, amongst library respondents, the two most frequently mentioned areas for improvement or change were stock and seating: $25 \%$ of library respondents stated that a greater availability of up-to-date books would make the library more appealing to them ('more copies of recent releases'; 'more stock on popular titles'; 'more recent book titles'); $17 \%$ of library respondents identified a need for seating facilities ('more seating, including in lending areas'; 'more casual seating - sofas, comfy chairs'; 'more comfortable seats'; 'seats in lending library'). Other suggestions by library respondents included: 'longer opening hours'; 'better displays'; 'displays of covers, not spines'; 'a café!', 'maybe a coffee bar or more events'. Bookstore respondents similarly identified stock as a key area for improvement, with $29 \%$ of this group stating that more up-todate and varied stock would make the library more appealing to them ('more up-todate books'; 'more up-to-date literature'; 'better selection of books'; 'faster access to newer books'). A need for improved café facilities was identified by $17 \%$ of bookstore respondents ('café'; 'coffee shop'; 'coffee bar'). Unlike library respondents who did not here refer to the issue of staff, $15 \%$ of bookstore respondents also identified staffing as an area for improvement ('less officious staff'; 'more helpful staff'; 'more enthusiastic staff'; 'friendlier assistants'). Other suggestions by bookstore respondents included: 'better opening hours'; 'comfy chairs'; 'sofas'; 'an idiot's guide to finding what you want'. 
Despite demand for comfortable reading space and café facilities in both locations, most respondents, when asked the final and wider question of whether or not the library and bookstore should look and feel different from each other, replied that they should. Explanations provided here by respondents effectively echo and reinforce trends throughout this study. For some respondents, the library is perceived as inherently educational, the bookstore as inherently recreational ("public libraries are meant for serious work; the bookstore is a place to hang out, relax, browse subjects and shelves'; 'bookstores are to browse; libraries are to research', 'libraries are mainly for information'; 'bookstore is more for personal reading'). Other respondents draw attention to the library's role in the community and the bookstore's commerciality ('they have different objectives - one to sell books, the other to provide a community service'; 'one's a business, the other a public service'), whilst a number of participants were found to simply regard the library and bookstore as places 'for' different groups ('they are different in their market'; 'libraries fulfil a need for the people in the community who can't afford books'; 'they're used by and aimed at different customers'; 'books tend to be borrowed by people who can't afford to buy books'). Amongst those believing the sites should look and feel the same, many expressed the view, again heard earlier in this study, that both the library and bookstore have a strong role to play in the promotion of books and reading ('both should make you want to read'; 'both should aim to make books exciting and appealing'; both have the same goal - to sell reading; both encourage love of books and other forms of information).

\section{Conclusions and recommendations}

This study sought to explore the impact of recent changes in book retailing on use, perceptions and expectations of the public library in the UK. By taking a 'snapshot' of the experiences of library and bookstore users in ten case study sites, it in effect sought to begin to understand whether or not change may be 'in store' for the public library as a consequence of the development and spread of the book superstore. Research was conducted only amongst those who already use bookstores and libraries and those predisposed to complete questionnaires or contribute to focus group discussions; the voices of groups such as non-users and children are unavoidably missing from this project.

Whilst its scope therefore inevitably demands that findings are treated with care, 'Change in Store' demonstrates that the high-street book superstore does appear for many respondents to be more than simply a space in which to purchase books. For some it is seen as a place for the community. For others, the bookstore is perceived and serves as a destination: a place in which to linger, to read, and to escape; a place in which to find information and to socialise; and a place with a role to play in reading promotion.

These functions have not been lost from the public library. What this study suggests, however, is that in order to retain a library service that is used by all, particular attention should be paid to the attitudes and behaviours of young people and middleincome earners, the groups most noticeably increasing their use of the bookstore, decreasing their use of the library (in the case of middle income earners) and holding the least favourable image of the library environment and service. It also suggests consideration be given to the desired balance of education and recreation in the future 


\section{Refereed article}

image and nature of the public library. At different points in this study, and through different means, it has been found that while the library appears to be strongly associated with focused research, information and education, the bookstore is in contrast associated with browsing, casual use and recreational reading. It is posited that the bookstore may yet become more strongly regarded as the leisure destination of choice for many readers.

\section{References and bibliography}

\footnotetext{
1 'Framework for the Future: Libraries, Learning and Information in the Next Decade' (London: Department of Culture, Media and Sport, 2003); 'Building Better Library Services' (London: The Audit Commission, 2003).

${ }^{2}$ Although the majority of questionnaire respondents (82\%) made at least some use of both bookstores and public libraries, bookstore and library respondents were found to make more use of their 'own' site (i.e. the site responded from). Respondents from bookstores and respondents from libraries are therefore treated as distinct populations in this study in order not to disadvantage the site less well represented in the final sample (libraries).
}

ASLIB (1995). Review of the public library service in England and Wales for the Department of National Heritage: final report. London: ASLIB.

Bohme, S. and Spiller, D. (1999). Perspectives of public library use 2: A Compendium of Survey Information. Loughborough: Library \& Information Statistics Unit.

Buckingham, L. \& Finch, J. (1998). "New kids on the blockbuster". The Guardian, 4" April 1998, 26. Coffman, S.(1998). "What if you ran your library like a bookstore?" American Libraries, 29 (3), 40-46.

Falk, P. (1997). “The scopic regimes of shopping”. In: Falk, P. \& Campbell, C. (eds), The Shopping Experience. London: Sage, 177-183.

Forrest, T. (2001). “Who's afraid of those declining adult issues?”. Library Association Record, 103 (3), 168-9.

Greenhalgh, L. (1993). The Place of the library. Bournes Green: Comedia.

Greenhalgh, L., Worpole, K. \& Landry, C. (1995). Libraries in a world of cultural change. London: UCL Press.

Gregory, D. (1998). “Book wars”. The Independent on Sunday, $2^{\text {nd }}$ August, 24.

Insight Research (1999). Usage of British public libraries: report on an exit survey, June, 1999. London: Insight Research.

Kotler, P \& Armstrong, G. (2001). Principles of Marketing. $9^{\text {th }}$ ed. Englewood Cliffs: Prentice Hall.

Kreitzman, L. (1999). “Shop around the clock”. The Bookseller, 26 $6^{\text {th }}$ March, no. 4865, p.36-8.

Landry, C. (1993). Fundamental Dilemmas for Public Libraries. Bournes Green: Comedia.

Library and Information Commission (2000a). Empowering the learning community: report of the Education and Libraries Task Group to the Secretaries of State for Culture, Media \& Sport, and for Education \& Employment, March 2000. London: Library and Information Commission. Available from: http://www.lic.gov.uk/publications/policyreports/empower/ [Accessed 25/02/04]. 
Library and Information Commission (2000b). Libraries: the essence of inclusion. London: Library and Information Commission. Available from:

http://www.lic.gov.uk/publications/policyreports/inclusion.html [Accessed 25/02/04].

McGuigan, J. (1996). Culture and the public sphere. London: Routledge.

MacLehose, C. \& Kneale, D. (2000). “Are bookshops losing the plot - and discerning readers?”. The Guardian, $15^{\text {th }}$ July, 2.

Marshall, C. \& Rossman, G.B. (1999). Designing qualitative research. $3^{\text {rd }}$ ed. Thousand Oaks: Sage.

Pennington, A.L. (1997). "Book superstores: reinventing book retailing”. International Trends in Retailing, 14 (2), 35-45.

Przybys, J. (2000). "Bookstores expanding role as community centers". Las Vegas Review Journal, Thursday, $3^{\text {rd }}$ August, section E, page 1E.

Ritzer, G. (1999). Enchanting a disenchanted world: revolutionizing the means of consumption. Thousand Oaks: Pine Forge Press.

St. Lifer, E. (2001). "What public libraries must do to survive". Library Journal, 126 (6), 60-62.

Sanderson, C. (2001). "Keeping up appearances”. The Bookseller, 18th May, 4975, $26-28$.

Sannwald, W. (1998). "Espresso and ambiance: what public libraries can learn from bookstores". Library Administration \& Management, 12 (4), 200-211.

Smith, K. (1999). “The bookshop as community space”. The Bookseller, $1^{\text {st }}$ October, no. 4892, p.31.

Torsi, S. (2001). "Borders offers customers much more than just a bookshop". Unpublished communication.

Walliman, N. (2001). Your Research Project. London: Sage.

\section{Executive summary}

This study investigates the impact of the book superstore on use and perceptions of public library space. The attitudes and behaviours of library and bookstore users were explored through focus group interviews and through a questionnaire placed in bookstores and central libraries in five cities in the UK.

\section{Results}

Analysis of impressions held of library and bookstore environments by questionnaire respondents revealed bookstores were generally regarded as warmer, smarter and more comfortable than libraries. Female respondents, older respondents $(60+)$ and respondents with a household income of under $£ 12000$ were found to rate the library environment more positively than did male respondents, younger respondents and those with a higher household income. Younger respondents were found to view the bookstore environment more positively than did older respondents.

The library was found to be much more widely regarded as a place for the community than was the bookstore; however, almost half of bookstore respondents agreed that the bookstore represents community space. Twice as many men as women were found to regard the bookstore in this way. Examination of reported use of the each site 
revealed higher proportions of men and those aged 17-29 in the bookstore sample than in the library sample. Of the different age groups, those aged 17-29 had most noticeably increased their use of the bookstore in the year preceding the study. Middle-income earners were found to have increased their use of the bookstore and decreased their use of the library. Results suggest the library and bookstore may in practice function as community space for two 'communities' largely separable by income.

Investigating behaviour associated with both sites revealed younger bookstore respondents were particularly unlikely to regard the library as a place in which to linger. Bookstore respondents were found to be more likely to sit, read or rest in the bookstore than library respondents were to sit, read or rest in the library. The library was found to be used more heavily than the bookstore as a place to study, work or to find information, and to be associated with education and 'defined retrieval'. In contrast, the bookstore was found to be more strongly associated with socialising, browsing and casual use.

Asked to describe any major differences in the 'look and feel' of each site, respondents focussed on stock and staffing. Library stock was frequently described as narrow and/or dated; bookstore stock as modern and up-to-date. Unlike the bookstore, the library was not found to be strongly associated with effective display or promotion. Bookstore respondents were found to be strongly critical of the customer care skills and enthusiasm of library staff.

Respondents stated that more up-to-date stock, comfortable seating, café facilities, and improved displays would make the library more appealing to them. It is postulated that the presence of the bookstore may be contributing to growing demand for such features. Respondents were, however, generally found to believe that the library and bookstore should look and feel different, regarding the library as inherently educational, the bookstore as inherently recreational, or suggesting that the sites serve different groups.

\section{Conclusions and recommendations}

Although it may be too early to speak conclusively of impact or of transfer of roles from the library to the bookstore, clear areas of overlap in function between the bookstore and library have been identified. There may also here be evidence of the beginnings of an income and age related split in use and perception of the bookstore and the library. It is thus recommended that in order to maintain a service that is used by all, attention be paid to the attitudes and behaviours of young people and middle income earners (the groups most noticeably increasing their use of the bookstore), and to the desired future balance of education and recreation in the image and nature of the public library.

\section{WORD COUNT: 6056}

